\title{
105 ワイヤロープ張力評価装置の開発
}

\section{Development of a wire rope tension meter}

$\begin{array}{cll}\text { ○学 川上 } & \text { 雄一郎 (大分大学) } & \text { 非 李 蓓 (東芝ロジスティクス) } \\ \text { 非 山口 } & \text { 安昭 (東芝ロジスティクス) } & \text { 正 三浦 篤義 (大分大学) } \\ \text { 正 永利 } & \text { 益嗣 (大分大学) } & \text { 正 今戸 啓二 (大分大学) }\end{array}$

Yuichiro KAWAKAMI, Oita University, 700 Dannoharu, Oita

Bei LI, Toshiba Logistics, 1-14 Nisshincho, Kawasaki-ku, Kawasaki, Kanagawa

Yasuaki YAMAGUCHI, Toshiba Logistics, 1-14 Nisshincho, Kawasaki-ku, Kawasaki, Kanagawa Atsuyoshi MIURA, Oita University, 700 Dannoharu, Oita

Masuji NAGATOSHI, Oita University, 700 Dannoharu, Oita

Keiji IMADO, Oita University, 700 Dannoharu, Oita

\begin{abstract}
It is important to know the tension of wire rope in use to avoid accident. But most of wire ropes are being used without knowing their tension. So far many ideas have been proposed to evaluate wire rope tension in use. However, few ideas have been realized to the present. We developed a simple wire rope tension meter that could be attached to a wire rope easily in use. The device applies twisting torque to a part of the wire rope by a stepping motor. A linear relation between wire rope tension and the torque obtained by the device was confirmed by the experiments. In addition, the change of wire rope tension and twisting torque with time were evaluated. They decreased gradually with time. Therefore a decrement of wire rope tension is able to be estimated by twisting torque. A simple model was proposed to account for a linear relation between the wire rope tension and twisting torque and hysteresis loop associated with twist loading on a rope. From these experimental studies, the device seems to be effective for evaluation of wire rope tension.
\end{abstract}

Key Words: Wire rope, tension meter, twisting torque, stepping motor, hysteresis loop

\section{1.はじめに}

ワイヤロープはワイヤと呼ばれる鋼線やステンレス線 をより合わせたストランドを，さらに心綱の周りに巻き 付けることで作られ(1)，大きな負荷能力と適度な柔軟性 のため，重量物の搬送，エレベータ，ケーブルカー，口 ープウェイ，吊り橋など，様々な所に利用されている. ところがワイヤロープの張力は，張力ベクトルの作用線 上にロードセルを設置すれば評価できるものの，ロード セルは精密で高価なため, 実㗢中の張力はほとんど評価 されることなく使われている。一方，ワイヤロープを取 り扱う現場の安全上，ロープ張力を後付式で簡便に測定 可能な装置の開発が望まれていることは言うまでもない. そこでワイヤロープの張力測定法として重直変位を与え

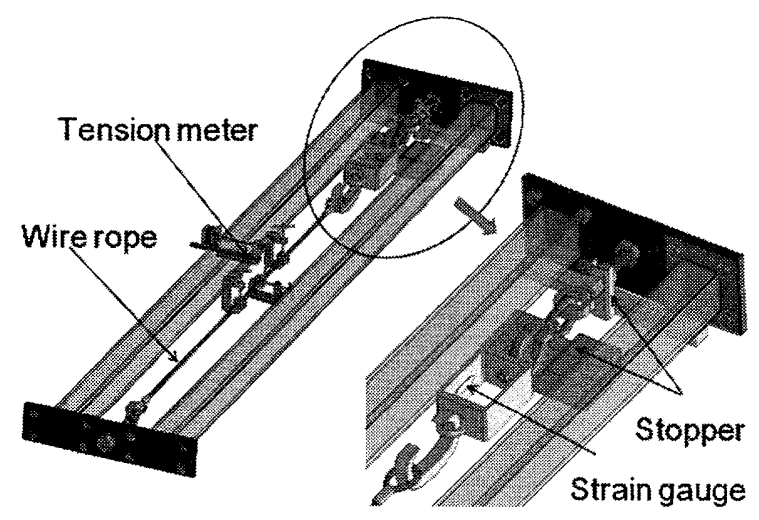

Fig.1 Experimental setup
る方法 ${ }^{(2)(3)}$, 偶力を与える方法(4), 横振動の周波数スぺ クトルより求める方法 (5), 横振動の振動数から求める方 法(6)など多数の提案がある。しなしながら何れも普及に は至っていない，材料力学のテキストにも紹介されてい る垂直変位を与える方法(2)(3) は, 長さ L のワイヤロープ に垂直荷重を与え，それによる重直変位から張力を算出 する。本来は垂直荷重を与えない状態の張力を知りたい のだが，この方法では理論的に不可能であり，大きな垂 直荷重と正確な垂直変位を必要とし, 得られる張力も垂 直荷重のため本来必要亡する值よりも大きくなる。

我々はワイヤロープの螺旋構造に着目し， ワイヤロー プの据じり剛性が螺旋構造のため張力に比例して強くな ることを実験的に確認し，モデルによる考察も行った(7). 前報(7)では手動でワイヤロープに据じり負荷を与えてお り，詳細な実験はできなかった。本報ではステッピング モータとねじを利用した据じり負荷装置を試作し，実験 した結果について報告する。

\section{2. 実験法}

$2 \cdot 1$ 張力負荷装置 図 1 はワイヤロープに所定の張 加を与える装置である. 長さ $2.2 \mathrm{~m}$ ，外寸 $76 \mathrm{~mm}$ の角鋼管 を 2 本平行に並べ, 中央に M 20 のねじ穴をあけた鉄板で 鋼管を連結しフレームとした。㸚じにはワイヤロープを かけるフックを取付け，フックの位置を权じにより動か すことで張力を与えた。㸚じを回す際のトルクがワイヤ ロープに作用しないよう，フックには回り止めを付けて いる.張力は薄板に貼ったひずみゲージにより検出した.

日本機械学会 [No.11-49] シンポジウム講演論文集 ['11-12-14〜15，大阪市，第 10 回 評価・診断に関するシンポジウム] 


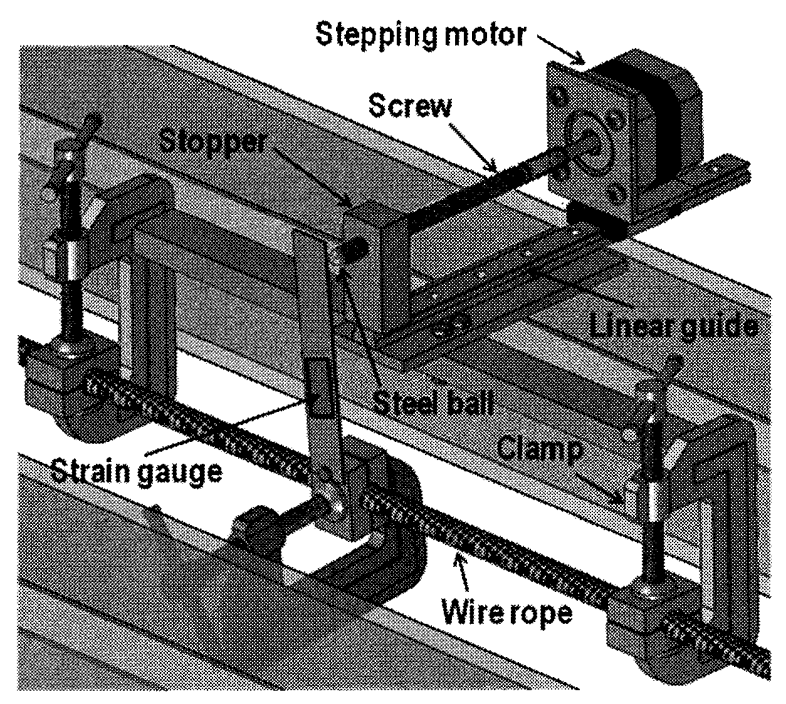

Fig.2 Enlarged view of wire rope twister

$2 \cdot 2$ ねじりトルク負荷装置 図 2 はステッピングモ 一タを利用したワイヤロープ用据じり負荷装置の外観を 示す. 外寸 $25 \mathrm{~mm} \times 12 \mathrm{~mm}$, 長さ $300 \mathrm{~mm}$ の鋼管の両端に, 市販のシャコ万を溶接してフレームとした．シャコ万に は半円筒溝加工したブロックを溶接し，ワイヤロープヘ の取り付けを容易にした。半円筒溝加工ブロックにねじ で固定した厚さ $1.2 \mathrm{~mm}$, 幅 $17 \mathrm{~mm}$, 長さ $135 \mathrm{~mm}$ の鋼鈑を, 据じりを与えるためのトルクアームとした．鋼鈑には負 荷トルク検出用ひずみゲージを貼り付けている.

フレーム中央にステッピングモータ取付用プレート $(40 \times 120 \times 5 \mathrm{~mm})$ を固定し，プレート端に M8 のめ放じを 加工したブロックを取り付けている．ステッピングモー タはリニヤガイドを介してプレートに取付けた．ステッ ピングモータは先端に鋼球を圧入した M8，ピッチ $1.25 \mathrm{~mm}$ のねじを回し，トルク負荷アームを押す。权じ の回転に伴いステッピングモータは㸚じと一緒にリニヤ ガイド上を移動する。ワイヤロープからの捩じりトルク 反力は衫じを介してブロックで受けるため，モータの軸 にスラスト方向の力は作用しない.

$2 \cdot 3$ 実験手順 最初にワイヤロープに所定の張力 6 〜 $10 \mathrm{kN}$ を与える.つぎに㧖じり負荷装置をワイヤロー プにシャコ万で固定する。最後にトルク負荷アームを装 置中央のワイヤロープにシャコ万により固定する。 なお トルク負荷アームを取付ける際, 鋼球先端と負荷アーム

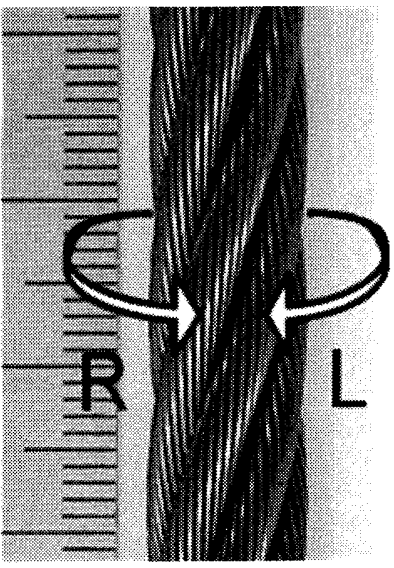

Fig.3 Wire rope tested
の距離が常に約 $3 \mathrm{~mm}$ 一定 になるよう治具を利用して セットした。 その後, シヤ コ万によりトルク負荷アー ムをワイヤロープに固定し た。実験はステッピングモ ータ駆動パルスをデジタル メモリの外部トリガーとし て使い, 㸚じ一回転当り 160 点の負荷トルクを記録 した。そのためデータは， 称じ移動 距 離 $1.25 / 160 \fallingdotseq 7.8 \mu \mathrm{m}$ 毎にサン プリングされる。亦じの移 動距離(押し込み距離) は特 に理由はないが, $25 \mathrm{~mm}$ と

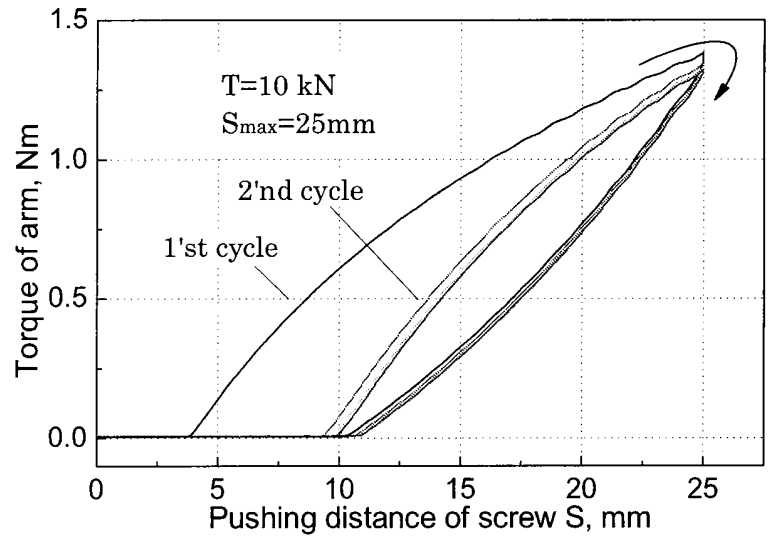

Fig.4 Hysteresis loop of torque applied to wire rope

$30 \mathrm{~mm}$ の二種類について実験した。押し込み過程では鋼 球は速度約 $6.4 \mathrm{~mm} / \mathrm{s}$ で進み, 最大ストロークに達すると 自動停止する。復帰ボタンを押すと出発地点に戻るよう に PIC を使い制御した．押込距離一定の条件下で時間に 伴うワイヤロープ張力と据じりトルクの減少を調べる実 験では，デジタルメモリの内部タイマーを利用して記録 した.

$2 \cdot 4$ 試験用ワイヤロープ 試験用ワイヤロープはフ ックにかけるために両端をアイ加工した外径 $10 \mathrm{~mm}$, 全 長 $1.5 \mathrm{~m}$ のものを使用した。図 3 に試験用ワイヤの写真 を示す。より方で分類 ${ }^{(8)}$ すると，ストランドが Z より， ワイヤ(素線)が $\mathrm{s}$ よりであるので, $\mathrm{sZ}$ より (ordinary lay right sZ) となる.

\section{3. 実験結果}

ねじの押し込み距離に伴う捻じりトルクを測定した一 例として, 図 4 にワイヤロープ張力 $\mathrm{T}=10 \mathrm{kN}$, 最大押し 込み距離 $\mathrm{S}_{\max }=25 \mathrm{~mm}$ である場合の捻じりトルクの変化 を示す。図は押し込み実験を繰り返し 4 回行った結果を 示している．押し込み開始部のトルクが 0 の部分は，鋼 球がトルク負荷アームに接触していないためである。卜 ルクの増加率は接触直後に最も大きく, 押し込み距離の 増加に伴い減少する。戻り行程はヒステリシスを描き, 初回押し込みの場合, 初回接触点から約 $6 \mathrm{~mm}$ 離れた点 で鋼球はトルクアームから離脱する。これはワイヤロー プ内の摩擦によるためであり，ある大きさの㸚り角内 ではワイヤロープは塑性的に振る舞う。2回目以降は接 触開始点と離脱点はかなり近づくものの, 塑性的性質は 消滅することはない。初回押し込み時のときにトルクは 最大となり，2回目以降は僅かに小さくなる。このこと は押し込み距離 $\mathrm{S}_{\max }=30 \mathrm{~mm}$ で行った実験でも同じであ ることを確認した。

図 5 (a)，(b)にそれぞれ押し出し距離 $\mathrm{S}=25 \mathrm{~mm}$ と $30 \mathrm{~mm}$ の場合についてのワイヤロープ張力 $\mathrm{T}$ と捻じりト ルク $\mathrm{R}$ の関係を示す。記号が 4 種類 $(\mathrm{R} 1 ， \mathrm{R} 4, \mathrm{~L} 1 ， \mathrm{~L} 4)$ あるのは，ワイヤロープに対する捻じり方向が図 3 に示 す $\mathrm{R}$ と $\mathrm{L} の 2$ 種類, 鋼球の押し出し回数を初回目と 4 回 目の 2 種類で合計 4 種類としたためである。例えば R4 は $\mathrm{R}$ 方向の㨝じりの 4 回目のデータという意味である. 図には最小二乗近似した直線もプロットしている.ばら つきはあるものの，捻じりトルク $\mathrm{R}$ は張力 $\mathrm{T}$ にほぼ比例 して増加する。それぞれの押し出し距離についての近似 直楾の勾配 $\mathrm{m}$ は， $25 \mathrm{~mm}$ の場合; $\mathrm{m}_{25}=0.0976,30 \mathrm{~mm}$ の場合; $\mathrm{m}_{30}=0.1196$ となり, $\mathrm{m}_{30} / \mathrm{m}_{25} \fallingdotseq 30 / 25=1.2$ とほ 


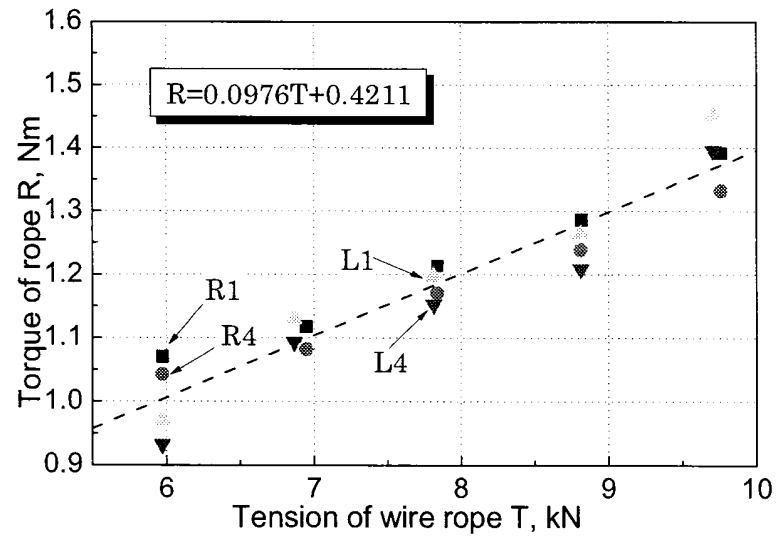

( a ) In the case of pushing is $25 \mathrm{~mm}$

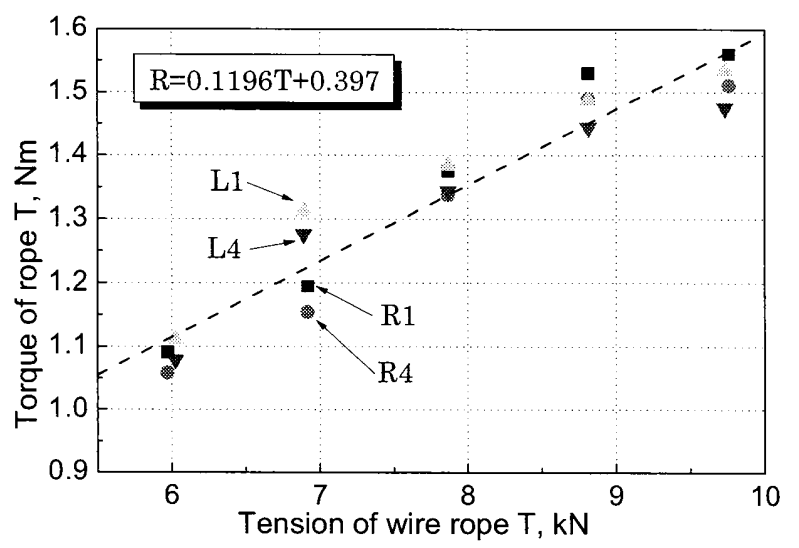

( $b$ ) In the case of pushing is $30 \mathrm{~mm}$

Fig. 5 Relation between torque and wire rope tension

ぼ押し出し距離 $\mathrm{S}$, 即ち捻じり角度に比例して大きくな る.

図 6 はワイヤロープに $\mathrm{T}=10 \mathrm{kN}$ の張力を与え, 押し出 し距離 $\mathrm{S}=30 \mathrm{~mm}$ の捻じりを与えたまま，放置した場合 の張力 $\mathrm{T}$ と捻じりトルク $\mathrm{R}$ の時間的変化を示す. それぞ れ時間とともに減少していくことが分かる．このことは 貨物をワイヤロープで固縛して輸送する際, 途中で増し 締めが必要となる可能性のあることを意味している。し かしながら現状はワイヤロープの張力を安価で科学的に 管理する方法がなく，作業者の勘と経験を頼りにしてい ることは問題である.

\section{4. 考察}

実験よりワイヤの一部を捻じるのに必要なトルク Rは 張力 T にほぼ比例して増加することが明らかとなった。 前報(7)では，ワイヤロープ長 $100 \mathrm{~mm}$ につき，90だけ 予め捻じりを与えた直径 $\mathrm{d}=3 \mathrm{~mm}$ のワイヤロープを, 万 能試験機により連続的に張力を増加させ, 張力 $\mathrm{T}$ とトル ク $\mathrm{R}$ が比例関係にあることを報告した. 張力 $\mathrm{T}$ とトルク $\mathrm{R}$ の比例関係は Klaus らの報告(8)(9)(10) と一致している. しかしながら前報(7)での実験方法や Klaus らの実験方法 (8)(9)(10)は現場では不可能なため, 現場で取り扱い容易な 後付け方式を考案して実験した. ワイヤ径が $\mathrm{d}=10 \mathrm{~mm}$ と 前報よりかなり剛性が増したため, $90^{\circ}$ 捻じり変形させ るには，捻じりトルクを大きくするか，ねじり長さを長 くする必要がある。簡単のためワイヤロープを連続体と 仮定すると, 捻じり剛性は極断面二次モーメントに比例

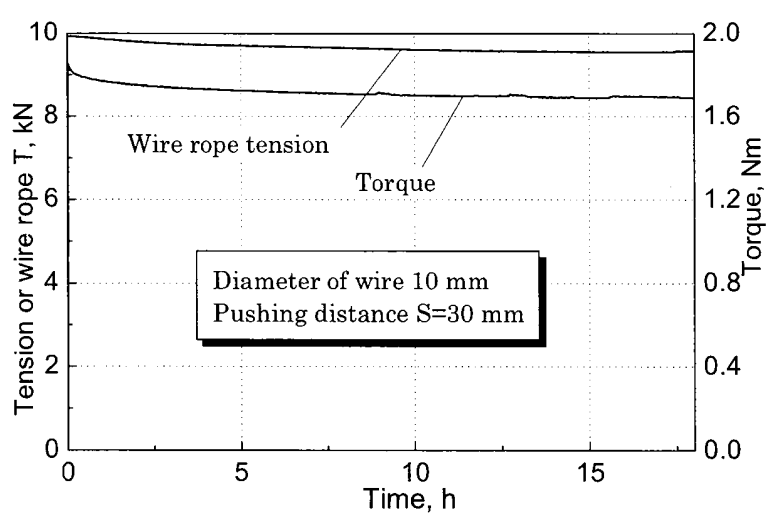

Fig.6 Tension of wire rope and twisting torque decrease gradually with time

するので, 直径 $\mathrm{d}=10 \mathrm{~mm}$ のワイヤロープの捻じり剛性 は, $\mathrm{d}=3 \mathrm{~mm}$ のワイヤロープの捻じり剛性の $(10 / 3)^{4}=123$ 倍にもなる.そこで $\mathrm{d}=10 \mathrm{~mm}$ のワイヤロープに, $\mathrm{d}=3 \mathrm{~mm}$ のワイヤロープと同じトルクで $90^{\circ}$ の捻じり変形させ るには， $12.3 \mathrm{~m}$ の長さが必要となり非現実的となる。今 回の実験では長さ $300 \mathrm{~mm}$ の中央に捻じりトルクを与え ているため，固定部を境に㧖じり方向は逆転し，それぞ れの捻じり部の長さは $150 \mathrm{~mm}$ となる. 中央を捻じる理 由は, ワイヤロープの捻じり剛性が捻じりトルクの方向 で異なるためである(8)(9)(10). 中央部を捻じることで両側 のワイヤロープの捻じり変形の向きは逆となり, ワイヤ ロープの構造に起因した捻じり剛性の異方性を小さくす るためと, 長さが不定となる試験部外側のワイヤの㧖じ り剛性の影響を排除する目的がある。図 5 の実験結果か らは，ばらつきはあるものの捻じり剛性の異方性は確認 できない。

ばらつきの原因は素線やストランドの摩擦が原因と思 われる. Costelloの著書(1)には摩擦の影響は非常に小さ いとされている。しかしながらそれは主に軸方向負荷を 受けた場合についての考察であり，本実験結果に適用す

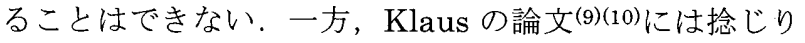
負荷を与えた場合について詳述し, トルクの理論式や使 い易くした式を提案し，代表的ワイヤロープに対する係 数表も示している。しかしながらこれらは長いワイヤロ 一プ全体を捻じった場合の実験結果であり，本実験のよ うにワイヤの一部を捻じったものではない。我々の実験 では押し出し距離 $30 \mathrm{~mm}$ の場合, ねじり角 $\phi$ は $\phi \fallingdotseq 10^{\circ}$ である．捻じり長さは $150 \mathrm{~mm}$ であるので, 単位長さ当 たりのねじり角 $\omega$ は， $\omega=67 \times 10^{-3} \circ / \mathrm{mm}$ となる。この 值は Klaus の論文( ${ }^{(8)}$ にる值と比較すると約半分である.

図 4 に示したヒステリシス曲線は張力に伴い微妙に形 状は変化する。そこで值の最も安定した 4 回目のヒステ リシスループについて, 閉曲線の面積を, 押し込み側曲 線(上側曲線) と $\mathrm{x}$ 軸との間の面積で除すことで, エネル ギー損失率を求めた。なお曲線内の面積はグリーンの補 助定理(11)を利用した線積分により求めた。 図 7 に結果を 示す. 図より張力の増加に伴いエネルギ一損失率は小さ くなることが分る，損失率が小さくなる理由は，摩擦損 失が張力には無関係とすると, 張力の増加に伴いワイヤ ロープの㧖じり剛性が増大した分だけ損失率は減少する ことになる. Klaus の著書(8)にある据じりトルクについ ての式でも張力とは無関係な項が含まれている，なお本 装置では回転鋼球とトルクアームとの間で滑りによる摩 


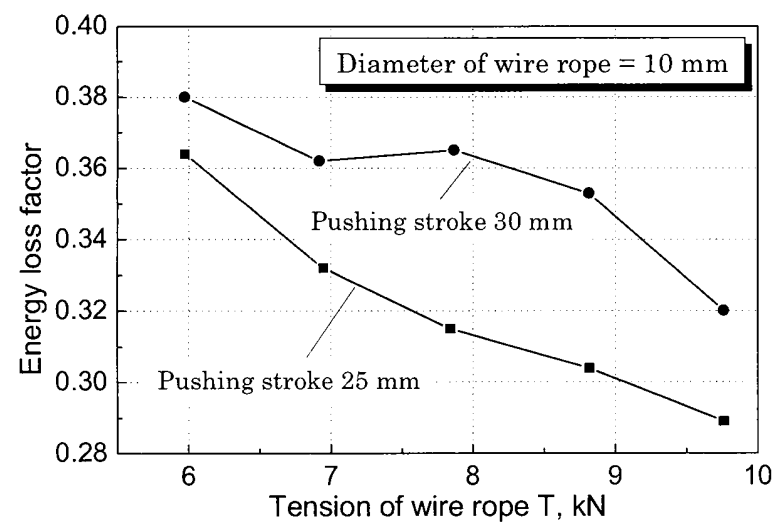

Fig.7 Energy loss factor associated with twisting decreases with tension of wire rope

擦損失もあるが，接触点に潤滑材を塗布してもほとんど 実験結果に影響しなかったので,その影響は考慮しない，

ワイヤの構造による摩擦損失については複雑なため簡 単には見積もれない，小野はワイヤ構造の数式による表 現法について詳細にまとめている(12)方, 摩擦力や応力の 計算までは言及していない，一方，Costello(1)と Klaus ${ }^{(8)}$ は応力の計算については詳述しているものの，構造の心゙ クトルによる表現法についての説明は希薄である。ここ では直感的に図 8 のような仮想モデルを考え，㨭じりに 伴う摩擦損失や張力に伴う据じり剛性の変化について考 える. 図 8 はワイヤロープの素線やストランドを仮想的 に平面に展開したイメージである。 ワイヤロープを捻じ ることは，水平面から $\theta$ だけ傾斜した仮想線に力 $\mathrm{P}$ を加 え，その傾きをさらにфだけ増すことになる，両端が拘 束された長さ L の細線の中央に垂直荷重 $\mathrm{P}$ を加え, 僅加 な垂直変位 $\delta$ が生じた場合, 張力 $\mathrm{T}, \mathrm{P}, \delta, \mathrm{L}$ の関係は,

$$
\mathrm{P}=\frac{4 \delta}{\mathrm{L}} \mathrm{T}
$$

で表わされる(2). 図 8 の仮想線は傾斜しているため，(1) に適当な修正係数をかける必要があるが本質的違いはな い. 変位 $\delta$ と長さ $\mathrm{L}$ が一定であれば, 垂直荷重 $\mathrm{P}$ は張力 Tに比例することを(1)は示している.そのため図 5 に示 したように, 捻じりトルク R はワイヤロープの張力 T に 比例する。一方，図 8 に示すモデルの $\mathrm{y}$ 方向を長さ $\mathrm{H}$ に 拘束した場合，力 $\mathrm{P}$ をえられることで仮想線同士は図 8 (b)に示すように軸方向に c だけ滑ることで摩擦が生じ る.しなしながら仮想線同士に作用力は仮想線の張力と はほとんど無関係である。仮想モデルによる考察は，ベ ルトを㨝じった際のトルクと張力の関係にも適用できる.

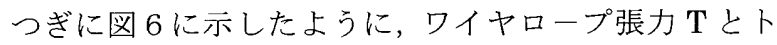
ルク R は時間とともに減少する。両者の関係を調べるた め，時間を消去して，それぞれの值を(2)式で定義する減 少率で比較した。

$$
\left.\begin{array}{c}
\Delta_{\mathrm{T}}=\frac{\mathrm{T}_{\max }-\mathrm{T}}{\mathrm{T}_{\max }} \\
\Delta_{\mathrm{R}}=\frac{\mathrm{R}_{\text {max }}-\mathrm{R}}{\mathrm{R}_{\max }}
\end{array}\right\}
$$

結果を図 9 に示す。実験開始直後にトルクは急に減少す るが，その後は張力減少率にほぼ比例するようになる。

図より張力は $4 \%$ ，トルクは $8 \%$ 以上低下したことが分 る。これらの結果より, ワイヤロープ張力を長期的にモ

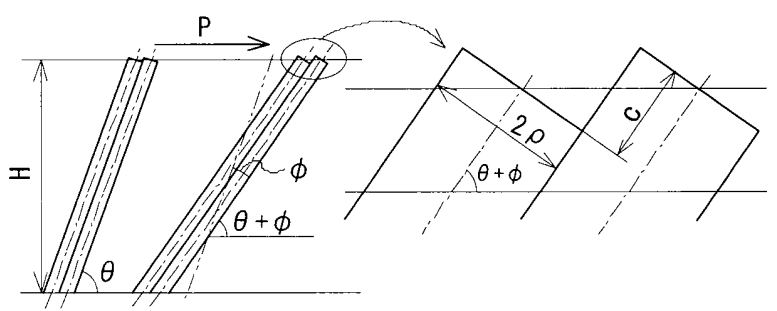

Fig. 8 Simplified model of wire rope in twisting

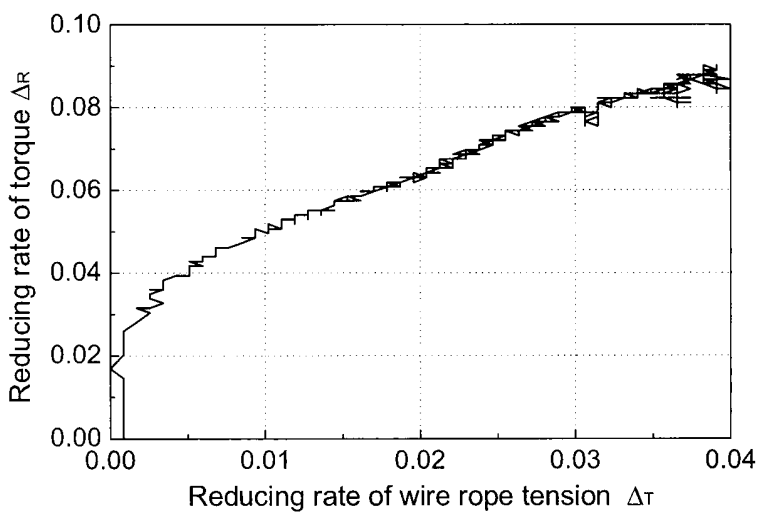

Fig.9 Relation between reducing rate of wire rope tension and twisting torque

ニターする際にも本張力評価装置は有効と思われる.

\section{5.まとめ}

ワイヤロープ張力の後付け式評価装置として，ステッ ピングモータを利用した㨝じりトルク負荷装置を試作し

た．得られた結果をまとめるとつぎのようになる。

1. 㨭じり角を一定にした場合, 㨭じりトルクは張力に 比例して增加する。

2. 据じりトルク負荷装置の負荷過程と除荷過程のトル ク值は摩擦によりヒステリシス曲線となる。

3.ヒステリシス曲線より求めた損失エネルギ一率は張 力の増大に伴い減少する.

4. ワイヤロープ張力は時間とともに減少し，それに対 応してトルク負荷装置のトルクも減少する.

\section{参考文献}

(1) George A. Costello, Theory of Wire Ropes, 2'nd Ed., Springer, pp.1-71, 1997.

（2）中原一郎, 材料力学, 上巻, pp.59, 養賢堂, 1983.

(3) Raymond J. Roark and Warren C. Young, Formulas for Stress and Strain, 5th Ed., McGraw-Hill, pp.171, 1975.

(4) 小堺元一, 張力測定具, 特開平 10-260096.

（5）村上卓也, 守谷敏之, ワイヤロープの張力測定方法, 特開 2001-153740.

(6) 中野政輝, エレベータのロープ張力測定装置, 特開 平 5-105349.

（7）川上雄一郎, 李湆, 山口安昭, 三浦篤義, 今戸啓二, ワイヤ張力の一評価法, 日本機械学会 中国四国支部 徳島講演会演論文集, pp.205-206,2010.

(8) Klaus Feyrer, Wire Ropes, Springer, pp.34-112, 2010.

(9) Klaus Feyrer and Gerhard Schiffner, Torque and 
torsional stiffness of wire rope - Part I, Wire Vol. 36, No.8, pp.318-320, 1986.

(10) Klaus Feyrer and Gerhard Schiffner, Torque and torsional stiffness of wire rope - Part II, Wire Vol. 37, No.1, pp.23-27, 1987.

(11) C.R.ワイリー，富久泰明訳，工業数学下巻，ブレイ ン図書出版, pp.595-599,1970.

(12) 小野進, 工学の数学ーワイヤロープの微分幾何学ー, アグネ技術センター, pp.57-142, 2005. 